\title{
Article \\ Exploring Viral Diversity in a Gypsum Karst Lake Ecosystem Using Targeted Single-Cell Genomics
}

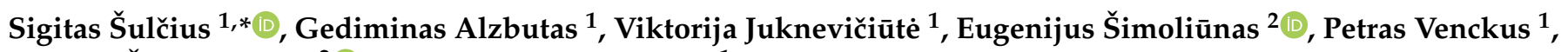 \\ Monika Šimoliūniene ${ }^{2}$ and Ričardas Paškauskas ${ }^{1}$ \\ 1 Laboratory of Algology and Microbial Ecology, Nature Research Centre, Akademijos Str. 2, \\ LT-08412 Vilnius, Lithuania; gediminas.alzbutas@gamtc.lt (G.A.); jukne.viktorija@gmail.com (V.J.); \\ petras.venckus@gamtc.lt (P.V.); ricardas.paskauskas@gamtc.lt (R.P.) \\ 2 Department of Molecular Microbiology and Biotechnology, Institute of Biochemistry, Life Sciences Centre, \\ Vilnius University, Sauletekio Av. 7, LT-10257 Vilnius, Lithuania; eugenijus.simoliunas@bchi.vu.lt (E.Š.); \\ monika.simoliuniene@gmc.vu.lt (M.Š.) \\ * Correspondence: sigitas.sulcius@gamtc.lt; Tel.: +370-693-78-443
}

Citation: Šulčius, S.; Alzbutas, G.; Juknevičiūtè, V.; Šimoliūnas, E.; Venckus, P.; Šimoliūnienè, M.; Paškauskas, R. Exploring Viral Diversity in a Gypsum Karst Lake Ecosystem Using Targeted Single-Cell Genomics. Genes 2021, 12, 886. https://doi.org/10.3390/genes12060886

Academic Editors: Dariusz Dziga and Benedykt Wladyka

Received: 4 May 2021

Accepted: 7 June 2021

Published: 8 June 2021

Publisher's Note: MDPI stays neutral with regard to jurisdictional claims in published maps and institutional affiliations.

Copyright: (C) 2021 by the authors Licensee MDPI, Basel, Switzerland. This article is an open access article distributed under the terms and conditions of the Creative Commons Attribution (CC BY) license (https:// creativecommons.org/licenses/by/ $4.0 /)$.

\begin{abstract}
Little is known about the diversity and distribution of viruses infecting green sulfur bacteria (GSB) thriving in euxinic (sulfuric and anoxic) habitats, including gypsum karst lake ecosystems. In this study, we used targeted cell sorting combined with single-cell sequencing to gain insights into the gene content and genomic potential of viruses infecting sulfur-oxidizing bacteria Chlorobium clathratiforme, obtained from water samples collected during summer stratification in gypsum karst Lake Kirkilai (Lithuania). In total, 82 viral contigs were bioinformatically identified in 62 single amplified genomes (SAGs) of C. clathratiforme. The majority of viral gene and protein sequences showed little to no similarity with phage sequences in public databases, uncovering the vast diversity of previously undescribed GSB viruses. We observed a high level of lysogenization in the C. clathratiforme population, as $87 \%$ SAGs contained intact prophages. Among the thirty identified auxiliary metabolic genes (AMGs), two, thiosulfate sulfurtransferase (TST) and thioredoxin-dependent phosphoadenosine phosphosulfate (PAPS) reductase (cysH), were found to be involved in the oxidation of inorganic sulfur compounds, suggesting that viruses can influence the metabolism and cycling of this essential element. Finally, the analysis of CRISPR spacers retrieved from the consensus C. clathratiforme genome imply persistent and active virus-host interactions for several putative phages prevalent among C. clathratiforme SAGs. Overall, this study provides a glimpse into the diversity of phages associated with naturally occurring and highly abundant sulfur-oxidizing bacteria.
\end{abstract}

Keywords: chlorobium phages; green sulfur bacteria; gypsum karst ecosystem; Kirkilai; Lithuania; Microviridae; Natura 2000; rare ecosystems; virus diversity; Single Cell Genomics

\section{Introduction}

Lakes of gypsum karst are small, yet very complex, aquatic ecosystems formed in sinkholes that emerge due to the erosion of gypsiferous dolomite bedrock. These endemic lakes can be characterized by strong thermal and chemical stratification, leading to contrasting gradients in redox potential and microbial metabolism [1,2]. Generally, aerobic oxygenic photolithoautotrophic processes dominate the surface waters of stratified lakes. In contrast, anaerobic anoxygenic photo/chemolithotrophic or heterotrophic processes (e.g., mediated by sulfur-oxidizing and sulfate-reducing bacteria) prevail in the euxinic (sulfuric and anoxic) layers of the water column [3-5]. Therefore, it might also be expected that bacterial communities in karstic lakes will exhibit pronounced vertical differences in taxonomic composition and gene content, corresponding to their physiological requirements and taxon-specific biogeochemical functions [1]. Although information about microbial diversity across the vertical gradients in (gypsum) karstic lake ecosystems remains scattered and 
fragmented (with very few sequencing datasets available in current public repositories), the available studies document the strong selective pressure of environmental factors on individual taxa in several karstic and stratified lakes [6-9]. In contrast, the role of the biotic factors, and especially of (bacterio)phages, remains poorly comprehended, leading to an insufficient understanding of the food web dynamics in these ecosystems. Consequently, there is a strong need to explore the diversity and genomic potential of phages in the context of the prevailing microbial assemblages throughout the environmental gradients of the karst lake ecosystems, and, more importantly, to identify the existing links between different members of viral and bacterial communities.

Phages are the most numerous and diverse component of the aquatic microbial food web. Phages can modulate cellular metabolism and regulate host population size, and through that, influence the biogeochemical cycles of essential elements (e.g., carbon, nitrogen, etc. $[10,11])$. They can mediate gene transfer between microorganisms and, therefore, contribute to species diversification and evolution. Currently, aquatic viromics (that is, metagenomics of the sample size fraction passing through $0.2 \mu \mathrm{m}$ filters) is the most commonly used approach to characterize the composition and structure of uncultured viral communities in the environments [12]. Although it enables the en masse sequencing of entire viral assemblages and to some degree provides quantitative community assessment, the taxonomic assignments and phylogenomic analyses are limited by the relatively short-read assemblies and the lack of reference viral genomes in public databases [13]. Alternatively, the sequencing of individual virions [14-16] or viral DNA cloned into fosmids $[17,18]$ enables us to obtain much larger DNA fragments, and even the entire genomes, from the environmental samples, although these approaches can either over- or underrepresent the most common members in the viral community $[15,19]$. In any case, the approaches mentioned above have mainly been used so far to represent a diversity of free viruses (in opposition to intracellular phages), implying that the host cells they have been infecting are already lysed and thus absent from the bacterial assemblages. In turn, this makes it difficult to establish links between the co-occurring viral and bacterial communities [13]. To overcome this issue and to establish possible associations between phages and bacteria, the single-cell sequencing and bioinformatic reconstruction of viral reads from within the single amplified genomes (SAGs) of the infected cells can be used [16,20-23]. If successful, the mining of SAGs datasets not only makes possible the discovery of novel phage genomes [24], but, more importantly, elucidates the ecological relevance and enables a more robust classification of viral sequences [23].

Lake Kirkilai $\left(56^{\circ} 14^{\prime} 55.5^{\prime \prime} \mathrm{N}, 24^{\circ} 41^{\prime} 33.7^{\prime \prime} \mathrm{E}\right.$; Biržai, Lithuania) represents a rare habitat of gypsum karst lakes (Natura 2000 code 3190), which are distinguished from other karstic ecosystems of a sinkhole origin (e.g., turloughs; Natura 2000 code 3180) by the permanent presence of water (EUR 28). This feature allows the formation of relatively stable hydrological and habitat connectivity across spatiotemporal scales, with potentially more resilient microbial communities than those in temporal karstic lakes [25,26]. Lake Kirkilai is a shallow (max. depth 6-7 m), nutrient- and organic matter-rich water body with high concentrations of $\mathrm{Ca}^{2+}$ and $\mathrm{SO}_{4}{ }^{2-}$ ions [27]. During summer stratification, the lake exhibits a pronounced chemocline at approximately $2 \mathrm{~m}$ deep, which is noticeable due to the depletion of oxygen, changes in water conductivity, and the presence of hydrogen sulfide $\left(\mathrm{H}_{2} \mathrm{~S}\right)$ [28-30]. These conditions are also accompanied by a significant shift in water temperature and density. Previous studies based on pigment analysis and partial 16S rRNA gene sequences obtained from the enrichment cultures revealed that members of genera Chlorobium (green sulfur-oxidizing bacteria; GSB) and Desulfovibrio (sulfate-reducing bacterium; SRB) are prevalent in the euxinic water layers of Lake Kirkilai [28-30]. At present, however, the relative abundance and distribution of these species, and any associations with other members of the lake bacterial or viral communities, are unknown.

This study aimed to explore the diversity of bacteriophages associated with the most common (keystone) taxa of the bacterial community in the Lake Kirkilai, a model system of the unique gypsum karst environment. Toward this aim, we first assessed the structure and 
distribution of the microbial assemblages across the vertical gradient of the water column using $16 \mathrm{~S}$ rRNA gene amplicon sequencing. Next, we applied targeted cell sorting to isolate and sequence individual cells of the most abundant taxa found in the euxinic water layers, a sulfur-oxidizing bacterium closely related to C. clathratiforme (formerly Pelodictyon phaeoclathratiforme; [31]). We were able to recover 82 viral contigs from 62 single amplified genomes (SAGs) of $C$. clathratiforme representing partial (74/84), near-complete (5/82), or complete (3/82) dsDNA and ssDNA (1 genome) viral genomes, including both lytic and temperate phages, putatively infecting members of the $C$. clathratiforme population. The identified viral sequences showed little or no similarity to other known phage sequences in public databases, nor were they similar to each other, suggesting the vast and largely overlooked diversity of phages associated with green sulfur bacteria. Some phages encoded auxiliary metabolic genes (AMGs) involved in sulfur metabolism, indicating an intervening role of viruses in the biogeochemical cycling of this element. By co-assembling and binning multiple and closely related C. clathratiforme SAGs, we reconstructed a near-complete (99\%) consensus genome of $C$. clathratiforme. Analysis of $C$. clathratiforme CRISPR arrays provides a glimpse into the dynamic interactions between $C$. clathratiforme and the putative phages identified in this study.

\section{Materials and Methods}

Water samples were collected via a hand-made submersible water collection device connected to an on-boat peristaltic pump. Water intake vents were set up every $0.5 \mathrm{~m}$ from surface to $5 \mathrm{~m}$ depth. The device was carefully immersed in water and left to settle for several hours before the sampling. This approach allowed us to collect water at the precise depth without intermixing different layers of the stratified water column.

Samples for $16 \mathrm{~S}$ amplicon sequencing were collected at $1 \mathrm{~m}, 3 \mathrm{~m}, 4 \mathrm{~m}$, and $5 \mathrm{~m}$ depths. At each depth, $10 \mathrm{~L}$ of lake water was first pre-filtered through $10 \mu \mathrm{m}$ Polycap AS filters (Millipore) and then collected (1-3 L) in Sterivex filter units $(0.22 \mu \mathrm{m}$, Merck KGaA, Darmstadt, Germany) using a peristaltic pump. Sterivex filter units were filled with $1.8 \mathrm{~mL}$ of lysis buffer (40 mM EDTA, $50 \mathrm{mM}$ Tris-HCL), flash-frozen in liquid nitrogen, and stored at $-80{ }^{\circ} \mathrm{C}$ until further processing. DNA was extracted using the phenol/chloroform approach according to descriptions in Riemann et al. [32]. For 16S rRNA gene fragment amplification, we used 515F-Y/926R primers [33], which target the V4-V5 region of the $16 \mathrm{~S}$ rRNA gene. Polymerase chain reactions (PCR) were carried out using $2 \times$ Phusion Master Mix with HF Buffer (ThermoFisher Scientific Baltics, Vilnius, Lithuania) and $1 \mu \mathrm{L}$ of genomic DNA as the template. The PCR cycling conditions included an initial $30 \mathrm{~s}$ denaturing step at $98^{\circ} \mathrm{C}$ followed by 30 cycles of denaturation at $98^{\circ} \mathrm{C}$ for $15 \mathrm{~s}$, annealing at $51{ }^{\circ} \mathrm{C}$ for $45 \mathrm{~s}$ and elongation at $72{ }^{\circ} \mathrm{C}$ for $45 \mathrm{~s}$, and a final elongation step at $72{ }^{\circ} \mathrm{C}$ for $90 \mathrm{~s}$. PCR fragments were excised from $2 \%$ agarose gels and purified with the GeneJET ${ }^{\mathrm{TM}} \mathrm{Gel}$ Extraction and DNA Cleanup Micro Kit (ThermoFisher Scientific Baltics, Vilnius, Lithuania). DNA libraries were generated using the Collibri ${ }^{\mathrm{TM}}$ PS DNA Library Prep Kit for Illumina Systems (ThermoFisher Scientific Baltics, Vilnius, Lithuania), and were normalized and pooled together before sequencing. Sequencing was conducted on an Illumina MiSeq platform using $2 \times 300 \mathrm{bp}$ paired-end reads based on the protocol at the ThermoFisher Scientific Baltics (Vilnius, Lithuania).

Samples for single-cell sequencing were collected at $3.5 \mathrm{~m}$ depth and processed as described in the SCGC protocol (scgc.bigelow.org (accessed on 17 July 2020)). Single-cell sorting, whole-genome amplification (WGA-X; multiple displacement amplification (MDA) of DNA that utilizes a thermostable mutant of the phi29 polymerase), and real-time PCR screens were performed at the Bigelow Laboratory Single Cell Genomics Center (bigelow. $\mathrm{org} / \mathrm{scgc}$ (accessed on 10 November 2020)). The sorting gates for the targeted sorting of Chlorobium bacteria were defined based on the autofluorescence of the characteristic cellular bacteriochlorophylls $c, d$, and $e$ (absorption maxima 715-745 $\mathrm{nm}$ ). Based on the effective WGA-X amplification of genetic material, a 384-well plate was selected for low-coverage shotgun sequencing with an Illumina end-paired HiSeq. 
The $16 \mathrm{~S}$ rDNA amplicon sequences were trimmed of adapters and quality-checked using the bbduk available in BBMap 37.17 package (jgi.doe.gov/data-and-tools/bb-tools / (accessed on 10 December 2020)) with the following settings: $\mathrm{ktrim}=\mathrm{r} ; \mathrm{k}=23$; $\operatorname{mink}=11$; hdist $=1 ;$ minlength $=50 ;$ maxns $=1 ;$ qtrim $=r$; trimq $=15$ tpe tbo. Singletons and chimeric sequences were removed before further processing of the sequence reads. Sequences in each sample were randomly subsampled using seqkit v0.7.0 [34] to 100,000 read pairs so that all samples had the same number of sequences (equal to the sample with the fewest total sequences). For the OTU analysis, the reads were initially merged using bbmerge from the BBMap 37.17 package. The de-replication was conducted using vsearch v2.14.2 [35] followed by clustering with swarm v3.0.0 [36] with the parameter $\mathrm{d}$ set to 2 . The taxonomic assignment of OTUs was conducted using a naïve Bayesian classifier from DADA2 (with minBoot) using the SILVA v138 database as a reference [37]. Sequence counts and taxonomic assignments of the most abundant OTUs ( $>0.1 \%$ from the total reads) were compiled in $\mathrm{R}$ and visualized using the phyloseq package v3.10 [38].

The obtained reads of SAGs were trimmed, normalized with kmernorm (https:// sourceforge.net/projects/kmernorm/ (accessed on 10 December 2020)), and assembled with SPAdes version: 3.13.1 [39]. The CheckM v1.0.12 [40] was used to estimate the genome size and completeness of SAGs. Then, contigs longer than $20 \mathrm{~kb}$ were merged into a single dataset and reassembled with SPAdes using the command-line option "-only assembler". In addition, assembly reads were merged and aligned using BBMap version 38.84 (sourceforge.net/projects/bbmap/ (accessed on 10 December 2020)), normalized using BBNorm with non-default command-line options "target $=100 \mathrm{~min}=1$ fixspikes $=\mathrm{t}^{\text {" }}$ and quality trimmed using BBDuk with non-default command-line options "ktrim $=\mathrm{r}$ $\mathrm{k}=23$ mink $=11$ hdist $=1$ tpe tbo qtrim $=\mathrm{r}$ trimq $=15$ threads $=12$ ". The overlapping reads were merged using BBMerge with default settings. The resulting contigs were once again reassembled with SPAdes. Viral sequences were identified using Vibrant v1.2.1 [41] and classified using Kraken2 [42] (viral DB version of 12/2/2020; benlangmead.github.io/ aws-indexes/k2 (accessed on 2 January 2021)) and Kaiju [43] (viral DB version of 2020-0525; kaiju.binf.ku.dk/server (accessed on 2 January 2021)). Distribution of identified viral contigs was assessed using BLASTn search against IMG/VR dataset (Ecosystem category: Aquatic; accessed June 2021; database version 5.1) with the average nucleotide identity of $\geq 95 \%$ over the alignment length of $\geq 85 \%$, and E-value $\leq 1$ considered as significant.

The consensus genome of $C$. clathratiforme was assembled using the MetaWRAP 1.3 bin refinement module [44] after the binning of contigs by MaxBin2 v2.2.6 [45], Concoot v1.0.0 [46], MetaBAT1 from MetaBAT2 v2.12.1 [47]. Prior to the binning procedure, $C$. clathratiforme contigs were classified using Kraken2 ("Standard" DB) and Kaiju ("nr" DB). Genome quality and completeness were evaluated using CheckM. The genomes were automatically annotated using PROKKA v1.14.5 [48]. CRISPR-Cas genes and arrays in the assembled consensus $C$. clathratiforme genome were identified using CRISPRCasTyper v 1.2.4 [49] and CRISPRidentify v 1.0.0 [50]. SpacePHARER v4.228b9e5 [51] was used to detect matches against viral contigs detected in SAGs and against GenBank_phage_2018_09 DB available within SpacePHARER.

Temperature, salinity, conductivity, and dissolved oxygen concentration were measured in situ using a multi-parameter portable meter MultiLine F/Set-3 (WTW). Nutrient concentrations, including nitrate, nitrite, and phosphate, were determined in a certified laboratory following standard procedures (ISO 7150-1, ISO13395-2000, ISO 11905-1:1997, and ISO 15681-1:2005).

\section{Results}

\subsection{Distribution of Bacterial Community throughout the Water Column of Lake Kirkilai}

Bacterial community composition in Lake Kirkilai was examined by 16S rRNA gene amplicon sequencing of water samples collected at four different depths: at the surface $(1 \mathrm{~m})$ and in the euxinic zone at $3 \mathrm{~m}, 4 \mathrm{~m}$, and $5 \mathrm{~m}$ depth; predefined by the in situ measurements of environmental variables (Table S1). In total, 3479 OTUs were identified by swarm 
v3.0.0 [36], with 267 singletons (7.7\%) and 1046 doubletons (30\%). Rarefaction curves reached a near plateau for samples taken at $1 \mathrm{~m}$ and $3 \mathrm{~m}$ depths (Figure S1), suggesting that these datasets can be considered sufficient to assess bacterial diversity. The rarefaction curve for samples taken at $4 \mathrm{~m}$ and $5 \mathrm{~m}$ depths did not reach a plateau (Figure S1), indicating that the diversity in these samples might be underestimated. Nevertheless, the calculated Shannon and Simpson diversity indices indicated moderate-to-high microbial diversity at all depths (Figure S2), except for the sample taken at $3 \mathrm{~m}$ depth, dominated by a single taxon (Figure 1; Table S2; also see below).

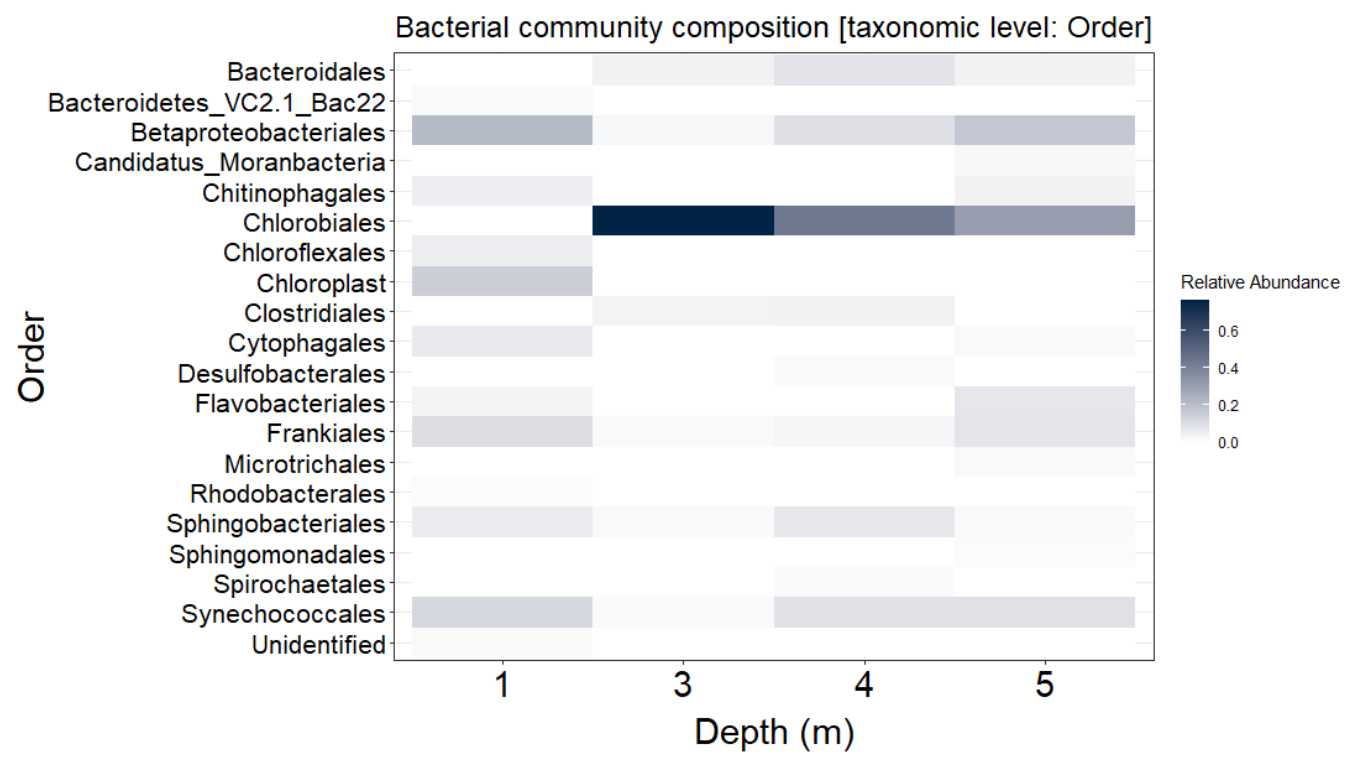

Figure 1. Bacterial community composition of the most abundant ( $>1 \%$ from total reads) taxa throughout the water column of the gypsum karst Lake Kirkilai (Lithuania).

A total of nine bacterial phyla comprising $1 \%$ or more of the total reads were identified (Table S2). Cyanobacteria were the dominant (33\%) phylum in the surface water layer, accompanied by major co-existing bacterial phyla such as Bacteroidetes (24\%), Proteobacteria (22\%) and Actinobacteria (12\%). In the euxinic water zone, members of order Chlorobiales were the most abundant, comprising up to $76 \%$ of the total bacterial abundance (Figure 1 ). Within Chlorobiales, most of the sequences were grouped into a single OTU (OTU2; Table S2) closely related to Chlorobium sp. This OUT was three orders of magnitude more abundant than the second-ranked OTU at the same depth (Table S2). The proportion of OTUs shared between the surface ( $1 \mathrm{~m}$, oxygenated water layer) and the euxinic water samples was $54 \%$, with the highest values (68\%) observed between $1 \mathrm{~m}$ and $5 \mathrm{~m}$ depths. The percentage of abundant OTUs (comprising $\geq 1 \%$ of total reads) shared between the samples taken from within the euxinic zone ( $3 \mathrm{~m}-5 \mathrm{~m}$; Table S1) was lower (18\%), suggesting stratification of the bacterial communities. The proportion of unclassified bacterial sequences, most of which were considered rare (e.g., accounted for less than $1 \%$ from the total reads), varied from $13 \%$ to $24 \%$, which may indicate either undersampled (e.g., at $4 \mathrm{~m}$ and $5 \mathrm{~m}$ depths; Figure S1) or still undiscovered diversity in the gypsum karst lake microbial assemblages.

\subsection{Bacterial Diversity within Single Amplified Genomes}

A total of 320 cells discriminated by size and fluorescence were sorted and subjected to MDA. The CheckM algorithm, which relies on the use of lineage-specific conserved marker genes, taxonomically classified 84 SAGs, of which 62 were identified as closely related to C. clathratiforme (Imhoff 2003, 2014; homotypic synonym of P. phaeoclathratiforme BU-1; Table S3, Figure S3), photoautotrophic reduced-sulfur compounds utilizing bacteria. The size of $C$. clathratiforme SAGs ranged between $24.5 \mathrm{~kb}$ and $1.55 \mathrm{Mb}$ (average size of $0.6 \mathrm{Mb} \pm 44.3 \mathrm{~kb}$ ), with the estimated genome completeness varying between $1 \%$ and $50 \%$ 
(average $18.1 \pm 10.9 \%$ ). All C. clathratiforme SAGs from which $16 \mathrm{~S}$ rRNA gene sequences were recovered fell into a single OTU based on clustering at the $99 \%$ identity threshold, indicating the clonal sequence diversity of the population. The remaining classified SAGs belonged to 11 different taxonomic orders (Table S3), mainly represented by a single SAG, similar to those observed by $16 \mathrm{~S}$ amplicon sequencing at $3 \mathrm{~m}$ and $4 \mathrm{~m}$ depths (Table S2). A large fraction of SAGs (236/320) were left unclassified due to the small size of the assembled genomes and the insufficient number of either taxon-specific marker genes or short sequence length of $16 \mathrm{~S}$ rDNA (Table S3). All but C. clathratiforme SAGs were discarded from subsequent analyses.

\subsection{Diversity and Distribution of Chlorobium clathratiforme-Associated Phage Sequences}

In total, 82 viral contigs were identified in 62 C. clathratiforme SAGs using VIBRANT, a protein similarity scoring-based approach enabling differentiation between viral and cellular sequences [41]. The size of the viral contigs ranged from $1.4 \mathrm{~kb}$ to $53.5 \mathrm{~kb}$, representing 3 complete, 5 near-complete (high quality) and 76 partial (low quality) genome sequences (Table S4). Further taxonomic classification of viral contigs was performed using Kaiju [43] and showed that among all classified viral contigs, members of Myoviridae (22\%) were dominating the viral community, followed by Siphoviridae (17\%) and Podoviridae (7\%) (Figure $2 \mathrm{a})$. A large fraction of viral contigs ( 48\%) was left taxonomically unassigned by the Kaiju algorithm (Figure 2a), although this proportion may change significantly if alternative classification methods are used (e.g., Kraken2; for details see Table S4). To assess the overall diversity of the viral contigs recovered from $C$. clathratiforme SAGs and to compare those sequences to publicly available genome databases, we used whole-genome-wide protein sequence similarity analysis available with ViPTree software [52]. We observed an almost complete lack of detectable genomic sequence similarities $\left(\mathrm{S}_{\mathrm{G}}<0.05 ; \mathrm{S}_{\mathrm{G}}=1\right.$ when genomes are identical and $S_{\mathrm{G}}=0$ when a tBLASTx analysis fails to detect any sequence similarities [52]) between viral contigs and the genomes in public repositories (Figure S4). Most of the viral contigs clustered by themselves (as singletons), which thus represented a significant fraction of the previously undiscovered diversity of viral gene and protein sequences. These findings were also consistent with the BLASTn search of viral contigs against the IMG/VR aquatic dataset (Table S5). Although some of the viral contigs had matches in various metagenomes (Table S5), none of them passed the suggested standard threshold of $95 \%$ average nucleotide identity over $85 \%$ alignment fraction [53].

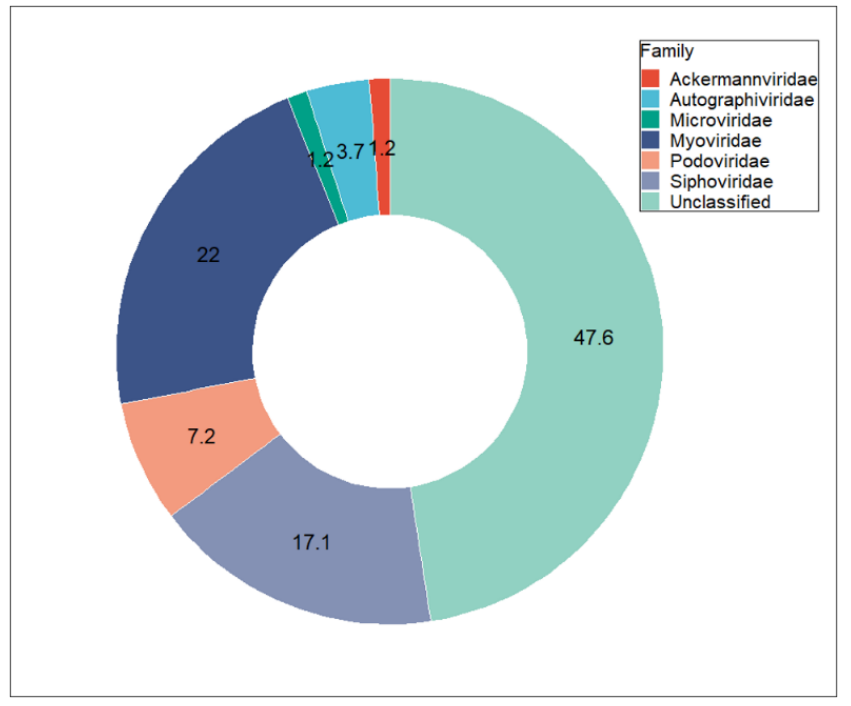

(a)

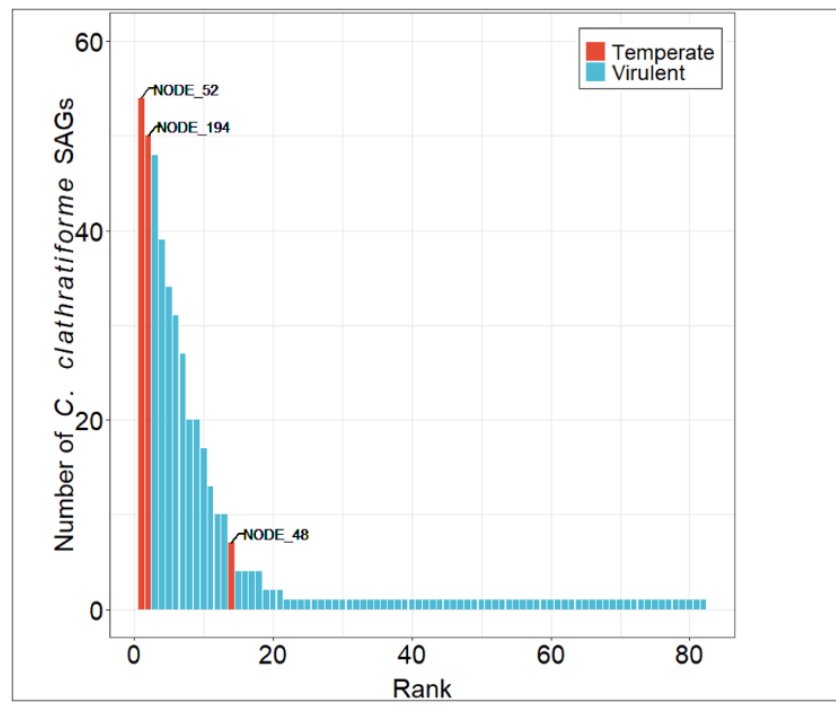

(b)

Figure 2. Taxonomic (Kaiju) classification (a) and distribution (b) of viral contigs recovered from 62 C. clathratiforme single amplified genomes (SAGs). Phage contigs were ordered by detection frequency among 62 C. clathratiforme SAGs. 
In total, 61 out of 62 C. clathratiforme SAGs contained at least 1 viral contig (Table S6), and up to 38 unique viral contigs were found in an individual SAG (SAG AH-978-L18; Table S6). The relative abundances of these contigs varied between the SAGs (Table S6), indicating extensive and rather individual cell-specific past and ongoing interactions between these bacterial and viral communities. Further, to assess the distribution of viral contigs within the $C$. clathratiforme population, we used fragment recruitment analysis against $C$. clathratiforme SAGs. This detection frequency analysis showed that the $C$. clathratiforme SAGs-associated viral community exhibited rank-abundance distribution (Figure 2b), reflecting the Bank model proposed by Breitbart and Rohwer [54]. In total, 14 viral contigs were found in more than $10 \%$ (six cells) of C. clathratiforme SAGs, while most of the other contigs were present only in individual cells (Figure 2b). Two contigs of putative viral genomes $(24.5 \mathrm{~kb}$ and $8.9 \mathrm{~kb})$, predicted to be temperate phages, were found in $87.1 \%$ (54/62; NODE_52; identified as integrated prophage by Vibrant software) and 80.6\% (50/62; NODE_194) of the C. clathratiforme SAGs, suggesting a high frequency of lysogenization within the C. clathratiforme population. One of these putative prophages (NODE_25; Table S4) can also be found in the type strain P. phaeoclathratiforme BU-1 genome, a green sulfur bacterium isolated from the meromictic lake in Germany [55], which indicates the non-endemic distribution of this temperate bacteriophage. The third putative prophage (NODE_48; Table S4) was found in $7(11.3 \%)$ out of 62 C. clathratiforme SAGs. Among the potentially lytic phage contigs, four (NODE_236, NODE_345, NODE_453 and NODE_232) were found in more than half of the analyzed SAGs (Table S4).

To further evaluate the diversity of C. clathratiforme SAGs-associated viruses, we focused on eight medium- and high-quality viral contigs, including two complete and five draft genomes classified as members of Caudovirales (Table S4), and one complete genome of the Microviridae family phage. The genome annotations of these viral contigs revealed that the overall genome organizations were in general similar to those observed in other bacteriophages belonging to different families of Caudovirales (Table S7). At the same time, both genomic alignments (Figure S4) and single gene phylogenies (Figure S5) performed at the amino acid sequence level indicated that the C. clathratiforme SAGs-associated viral contigs observed in this study share little sequence conservation with viral genomes in public databases and, therefore, represented potentially new viral species, and in most cases likely new genera as well. The phylogenomic reconstruction (neighbor-joining method after alignment with MAFFT [56]) based only on the conserved genome sites of 1 Microviridae genome (NODE_396) recovered from C. clathratiforme SAGs and 62 reference Microviridae genomes (RefSeq viral DB; accessed in March 2021) showed that the C. clathratiforme SAGs-associated Microviridae genome (NODE_396), although grouped with Bullavirinae by the used algorithm, clustered distantly from other known Microviridae phages within the tree (Figure 3), indicating little similarity to these phages. The complete genome alignments using VIRIDIC [57], however, demonstrated slightly higher similarities between the C. clathratiforme SAGs-associated Microviridae genome (NODE_396) and Microviridae genomes retrieved from RefSeq DB (Table S8). For example, the Microviridae genome (NC_028994), reconstructed from viromes collected in Boiling Springs Lake (an acidic fumarole-heated lake) in the USA, showed 51.7\% nucleotide sequence similarity at the whole-genome level (Table S8), suggesting that the two viruses may belong to the same genera [58]. 


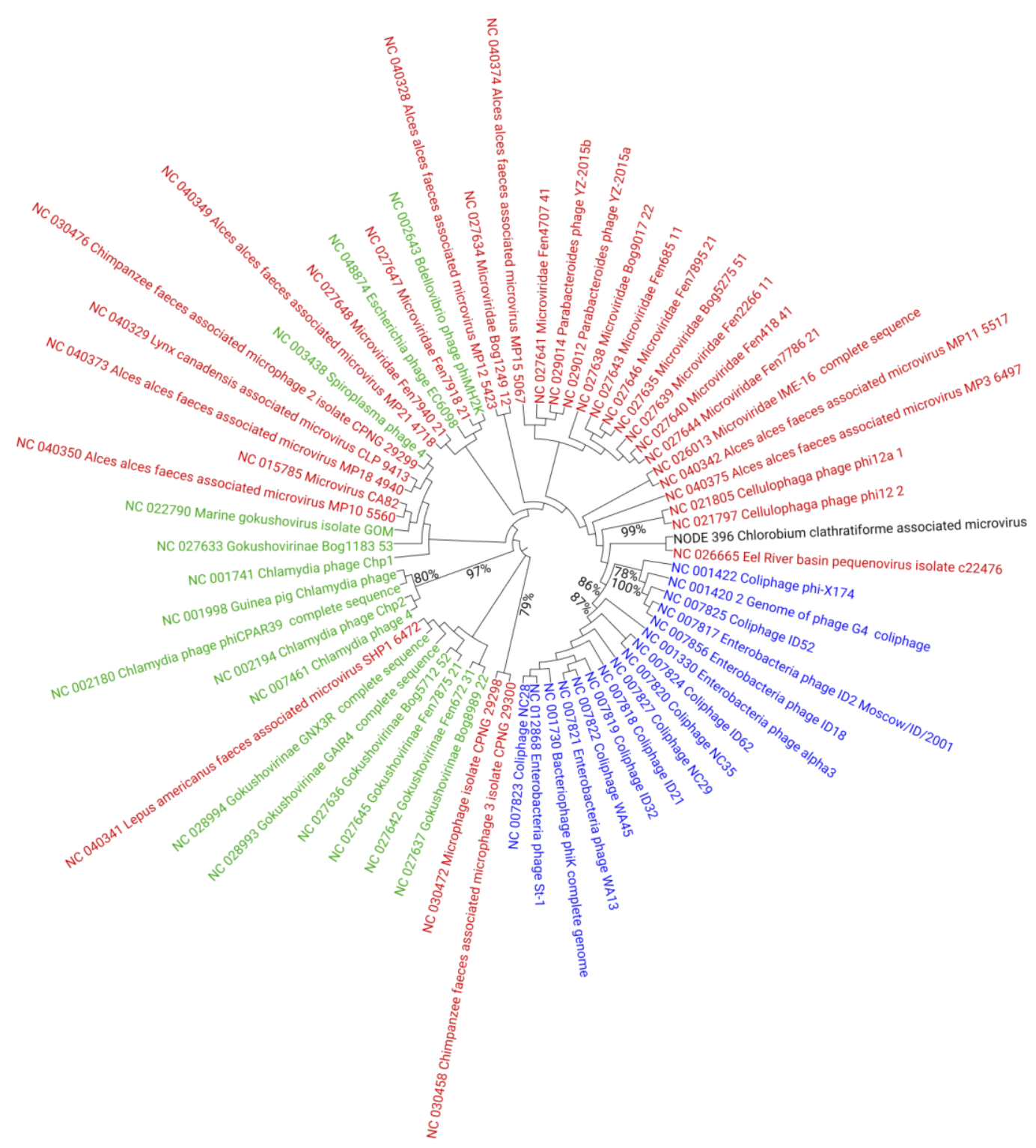

Figure 3. Phylogenetic tree reconstruction of Microviridae family bacteriophages (RefSeq DB; accessed on March 2021) and representation of $C$. clathratiforme SAGs-associated Microviridae genome (NODE_396). Members of Bullavirinae are marked in blue, members of Gokushovirinae are marked in green and unclassified microviruses are marked in red. The C. clathratiforme SAGs-associated Microviridae phage genome (NODE_396) is shown in black. The tree was calculated using a neighbor joining algorithm of the conserved sites in the genomes, with the bootstrap values higher than $75 \%$ given at the nodes.

\subsection{Gene Content Analysis of Chlorobium clathratiforme-Associated Phage Sequences}

In total, 1261 predicted open reading frames (ORFs) were recovered from 82 C. clathratiforme SAGs-associated viral contigs (Table S9). A large fraction of ORFs (855, or $68 \%$ of the total number of ORFs) were considered to be hypothetical proteins. At the same time, most of the identified phage ORFs possessed functions of viral DNA replication (e.g., helicases, primases, polymerases, etc.) and packaging enzymes (e.g., terminases), virion morphogenesis and structural genes (portal, minor and major capsid, tail tape measure, baseplate, etc.), as well as those required for cell entry (e.g., cell wall-associated hydrolase) and cell wall lysis (e.g., lysozyme, holin, etc.). The other identified ORFs were encoding proteins involved in virus-host interactions and various cell metabolic processes, including host signaling, methylation, recombination, nutrient cycling, antibiotic resistance, and transmembrane transfer of different molecules (Table S9). Thirty putative auxiliary metabolic genes (AMGs) were detected in viral contigs (Table 1), including those involved in amino 
acid, carbohydrate, and secondary metabolite metabolism. Most of these AMGs are commonly found among other marine and freshwater bacteriophage genomes (e.g., [59]). More intriguingly, two AMGs, TST and $c y s H$, encoding, respectively, thiosulfate sulfurtransferase and thioredoxin-dependent phosphoadenosine phosphosulfate (PAPS) reductase, associated with sulfur metabolism were found in C. clathratiforme SAGs-associated viral contigs (Table 1). The BLASTp search of these AMGs against the Chlorobium/Pelodictyon database (NCBI taxid:274493) and C. clathratiforme SAGs revealed no significant hits, suggesting early differentiation of these genes throughout the co-evolutionary history of C. clathratiforme and its putative phages. A putative phosphate transport regulatory protein, which was hypothesized to be involved in phosphate scavenging and oxidative stress response, encoded by phoU was also identified (Table 1). Finally, four viral contigs were found to encode ribosomal proteins (L1, L18 and S10) and one ribosome-associated GTPase (Table S9). These genes were recently shown to be widespread among aquatic phages and were proposed to be involved in host metabolism takeover during infection [60]. The discovery of these AMGs broadens the known functional gene repertoires and metabolic potentials of aquatic viruses.

Table 1. Auxiliary metabolic genes identified in C. clathratiforme SAGs-associated viral contigs.

\begin{tabular}{|c|c|c|c|c|}
\hline Metabolism & Pathway & Total AMGs & AMG KO ${ }^{a}$ & AMG KO Name \\
\hline \multirow{9}{*}{ Carbohydrate metabolism } & Pentose phosphate pathway & 1 & K07404 & pgl; 6-phosphogluconolactonase \\
\hline & Fructose and mannose metabolism & 4 & K01711 & Gmd; GDPmannose 4,6-dehydratase \\
\hline & & & K02377 & fcl; GDP-L-fucose synthase \\
\hline & Galactose metabolism & 1 & K01784 & gale; UDP-glucose 4-epimerase \\
\hline & $\begin{array}{l}\text { Amino sugar and nucleotide } \\
\text { sugar metabolism }\end{array}$ & 7 & K01709 & rfbG; CDP-glucose 4,6-dehydratase \\
\hline & & & K01711 & Gmd; GDPmannose 4,6-dehydratase \\
\hline & & & K02377 & fcl; GDP-L-fucose synthase \\
\hline & & & K13010 & $\mathrm{rfbE}$; perosamine synthetase \\
\hline & $\begin{array}{l}\text { C5-Branched dibasic acid and } \\
\text { Butanoate metabolism }\end{array}$ & 1 & K01652 & $\begin{array}{l}\text { ilvB, ilvG, ilvI; acetolactate synthase I/II/III } \\
\text { large subunit }\end{array}$ \\
\hline \multirow[t]{2}{*}{ Energy metabolism } & Sulfur metabolism & 2 & K00390 & $\begin{array}{l}\text { cysH; thioredoxin-dependent } \\
\text { phosphoadenosine phosphosulfate } \\
\text { (PAPS) reductase }\end{array}$ \\
\hline & & 2 & K02439 & $\begin{array}{l}\text { TST; thiosulfate sulfurtransferase } \\
\text { (rhodanese) }\end{array}$ \\
\hline \multirow{7}{*}{ Amino acid metabolism } & $\begin{array}{l}\text { Alanine, aspartate and } \\
\text { glutamate metabolism }\end{array}$ & 1 & K01953 & $\begin{array}{l}\text { asnB; asparagine synthase } \\
\text { (glutamine-hydrolyzing) }\end{array}$ \\
\hline & Glycine, serine and threonine metabolism & 1 & K00613 & Glycine amidinotransferase \\
\hline & Cysteine and methionine metabolism & 3 & K00558 & dcm; DNA (cytosine-5)-methyltransferase \\
\hline & & & K00789 & metK; S-adenosylmethionine synthetase \\
\hline & Valine, leucine, and isoleucine biosynthesis & 1 & K01652 & $\begin{array}{l}\text { ilvB, ilvG, ilvI; acetolactate synthase I/II/III } \\
\text { large subunit }\end{array}$ \\
\hline & Arginine and proline metabolism & 1 & K00613 & Glycine amidinotransferase \\
\hline & Cysteine and methionine metabolism & & K00558 & dcm; DNA (cytosine-5)-methyltransferase \\
\hline \multirow{3}{*}{$\begin{array}{l}\text { Metabolism of cofactors } \\
\text { and vitamins }\end{array}$} & Pantothenate and CoA biosynthesis & 1 & K01652 & $\begin{array}{l}\text { ilvB, ilvG, ilvI; acetolactate synthase I/II/III } \\
\text { large subunit }\end{array}$ \\
\hline & Porphyrin and chlorophyll metabolism & 1 & K04034 & $\begin{array}{l}\text { bchE; anaerobic } \\
\text { magnesium-protoporphyrin IX } \\
\text { monomethyl ester cyclase }\end{array}$ \\
\hline & $\begin{array}{l}\text { Ubiquinone and other } \\
\text { terpenoid-quinone biosynthesis }\end{array}$ & 2 & K03183 & $\begin{array}{l}\text { ubiE; demethylmenaquinone } \\
\text { methyltransferase/2-methoxy-6- } \\
\text { polyprenyl-1,4-benzoquinol } \\
\text { methylase }\end{array}$ \\
\hline Unclassified & - & 1 & K02039 & phoU; phosphate transport system protein \\
\hline
\end{tabular}




\subsection{Analysis of CRISPR-Cas Loci in the Chlorobium clathratiforme Genome}

By pooling and co-assembling reads from 62 C. clathratiforme SAGs, we reconstructed a consensus genome of $C$. clathratiforme (Supplementary File S1). The estimated completeness of the whole-genome assembly was $99 \%$, and the resulting chromosome was $4.0 \mathrm{Mbp}$ in length. In total, 3831 protein-coding genes, 2283 of which were annotated encoding hypothetical proteins, were identified using PROKKA software [48]. The assembled genome showed $98 \%$ average nucleotide identity to the type strain P.phaeoclathratiforme BU-1. Three CRISPR arrays (CRISPR1-3) were found in the assembled C. clathratiforme consensus genome (Table 2) and were based on the presence and position of the specific cas genes. They were assigned to subtypes III-A (CRISPR1), I-C (CRISPR2) and unknown (CRISPR3; contained only cas1 and cas2). All CRISPR arrays were associated with specific identical repeat sequences, while only subtype III-A appeared to have fully functional cas gene clusters with modules for spacer insertion (cas1/cas2) and target interference (various cas, csm, cmr genes; Table 2). In total, CRISPR arrays harbored 152 (CRISPR1-40, CRISPR2-31, CRISPR3 - 81) different spacers (Table S10), most of which were unique. A SpacePHARER search using all observed CRISPR spacers as a query found 14 significant hits to both $C$. clathratiforme SAGs-associated viral contigs observed in this study and viral genome sequences available in public databases (viralDB; accessed in March 2021; Table 2). Five different spacers from all three CRISPR arrays were found to target the same viral contig (NODE_31; Table 2), though different regions within the viral genome (all but one encoding hypothetical proteins). The positions of these spacers within the CRISPR arrays varied from the leader end (e.g., CRISPR2:1; Table 2), representing the most recent acquisition, to the middle-trailer end (e.g., CRISPR3:66; Table 2), where the oldest spacers in the locus reside. Fewer spacers, yet similarly distributed along the CRISPR arrays, were also found against the other two abundant viral contigs (NODE_113 and NODE_48; both contigs were found in more than $10 \%$ of $C$. clathratiforme SAGs; Table S4), indicating previous and ongoing co-evolution between these viruses and their hosts. Two spacers were found to have matches in C. clathratiforme SAGs-associated Microviridae genomes (NODE_396; CRISPR2:5) and in Microviridae sp. isolate ctec913 (CRISPR2:16), which was recovered from animal viromes [61]. 


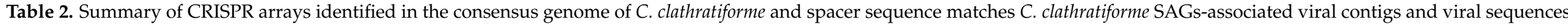
in publicly available repositories (accessed on March 2021)

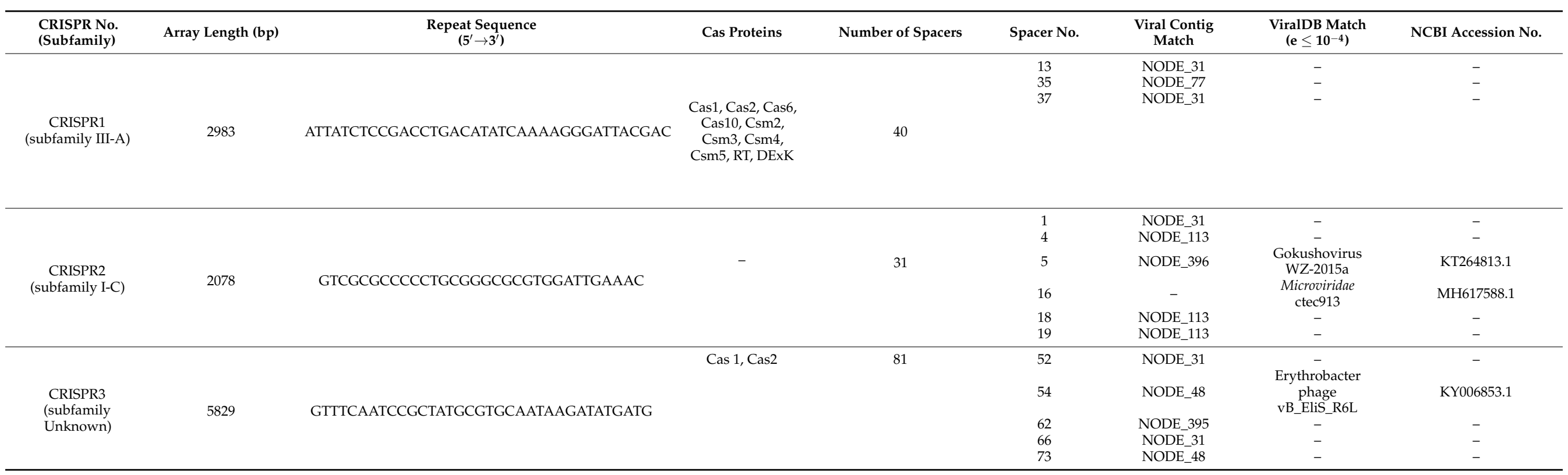




\section{Discussion}

The knowledge about the diversity and distribution of viruses infecting green sulfur bacteria (GSB) is still extremely sparse. A few available studies have revealed the previously unexplored sequence space and heterogeneity of GSB-associated viruses [8,23]. It was also demonstrated that these phages are active and highly dynamic, and can play a significant role in the evolution of their hosts [8,23]. Here, we presented an analysis of viral sequences recovered from $C$. clathratiforme single-cell amplified genomes, further uncovering the genomic structure and repertoire of putative phages associated with these naturally occurring, highly abundant, sulfur-oxidizing bacteria. However, the relationships between recovered viral contigs and C. clathratiforme SAGs should still be interpreted with some caution, as there is a chance that some of these viral contigs might have originated from accidentally co-sorted free virus particles. Nevertheless, our study specifically revealed (i) new genetic information (Table S8) about the distribution (Figure 2) of the viral community associated with C. clathratiforme, (ii) the high level of lysogenization in the C. clathratiforme population (Table S4), (iii) the genomic potential of phages to contribute to biological sulfur cycling via viral-encoded AMGs (Table 1), and (iv) the dynamic nature of interactions between specific putative phages and C. clathratiforme (Table 2). Our results suggest that C. clathratiforme might be a host organism for Microviridae phages (Table 2, Table S4). Finally, we also suggest that $C$. clathratiforme is likely a "keystone" species in Lake Kirkilai (Figure 1), which represents a model gypsum karst lake ecosystem (EUR 28). Altogether, these findings contribute to an improved understanding of the ecological complexity of rare and unique environments.

The majority of viral gene and protein sequences determined in this study were classified as "unknown" and lacked detectable homologs in public sequence databases. In this regard, our findings are similar to those in Llorens-Marès et al. [8] and Berg et al. [23], which used bioinformatic approaches to reconstruct and analyze putative phage contigs and genomes associated with GSB from metagenomes. The researchers found low percentages of gene/genome sequence similarities between GSB-associated and other known viruses in these studies. Using comparative genomics analysis, they also observed that GSBassociated viral contigs clustered at a distance from other phages, potentially representing novel and separate viral lineages $[8,23]$. This is not unexpected, however, and such a high number of "unknowns" can be attributed to both vastly undersampled euxinic environments dominated by GSB [62] and the highly divergent nature of members of Caudovirales. The high diversity of viruses potentially infecting GSB may be associated with the highly specialized and endemic (ecotypes) distribution of GSB species, as well as to the modular structure of virus-host interactions [63], which in turn prevents cross-taxon genomic recombination between co-infecting phages resulting in genetically discrete populations [64]. Finally, the lack of identifiable genes in common between C. clathratiforme SAGs-associated viral contigs and those characterized in Llorens-Marès et al. [8] and Berg et al. [23], as well as the presence of the high number and diversity of spacers in the C. clathratiforme CRISPR loci (Table S9) with no matches to known viral sequences, suggests that the much broader diversity of GSB viruses awaits future discoveries.

In addition to the observed large number and high diversity of $C$. clathratiforme SAGsassociated viral contigs, our study also suggests coinfections in the $C$. clathratiforme population (average - 7 viral contigs/SAG, median -6 viral contigs/SAG; Table S6). Even though recovered phage sequences may represent remnants of past infections, they are still an indication of the extensive virus-host interactions and increased eco-evolutionary pressure on both host bacteria and their phages, including the phage life cycle decision (e.g., lytic vs. lysogenic; [65]). The conversion from the lytic to lysogenic replication pathway may have significant implications for phage distribution within the host population [66,67]. In this study, we found that most of $C$. clathratiforme SAGs $(87 \%)$ contained a putative prophage (Figure 2b), revealing a high level of lysogenization within the C. clathratiforme population. Similarly, Berg et al. [23] found that some of GSB populations can be persistently 
infected (throughout $\sim 11$ years) by the temperate phages at very high rates $(\sim 100 \%$; [23]). Attempting to explain these observations, Berg and colleagues [23] proposed that the clonal composition of the host population, concomitant with a low rate of prophage induction, might promote the distribution of temperate phages within the population. Our findings of prophage prevalence in most of the C. clathratiforme SAGs (54/62), all of which have high $(>99 \%)$ 16S rRNA gene nucleotide sequence similarity, agree with the hypothesis described in Berg et al. [23]. On the other hand, however, it has been shown that an increased level of co-infections may also promote the rate of genome integrations of temperate phages (life-cycle decision; $[67,68]$ ). The lysogenization rate of the host population can also be density-dependent ("Piggyback-the-winner" (PtW) hypothesis; [68]). Thus, the high level of $C$. clathratiforme lysogenization observed in our study can be explained by a combination of several factors, including the clonal composition [23] and high density (PtW strategy; [68]) of the host population (Figure 2, Table S2), as well as by the high levels of coinfections by the co-occurring phages (Table S6). From the phage perspective, lysogenization may provide a competitive advantage against other co-infecting phages (super-infection exclusion; e.g., [69] and references therein) and ensure more stable coexistence between the phage and its host on a temporal scale, such as during the periods of GSB blooms.

Numerous metagenomic surveys revealed that extremely diverse viral communities often exhibit species-rank abundance distribution [70]. These observations led to the development of the Bank model hypothesis [54], which states that at any given time, there is only a small subset of highly abundant viruses complemented by a large number of rare genotypes. This fraction of rare viruses is maintained at low densities until their suitable hosts reach abundances high enough to promote their replication, leading to changes in the dominant viral genotypes [54]. The C. clathratiforme SAGs-associated viral contigs showed rank-abundance distribution at the population level (Figure 2b) similar to that typically observed for entire viral communities, thus demonstrating the existence of the same principles proposed in the Bank model at a lower organizational level. Such distribution of putative $C$. clathratiforme phages may also imply that temperate phages, at least at the time of sampling and in the presence of clonal composition of the host population, were relatively more "successful" than most of the lytic phages. The observed distribution of putative $C$. clathratiforme phages (Figure $2 b$ ) also fits quite well with the distribution of CRISPR spacers in the C. clathratiforme genome (Table 2). For example, the highest number of spacers (Table 2) was observed against the putative phages that were relatively more abundant (found in more than $10 \%$ of SAGs, e.g., NODE_31, NODE_48, and NODE_113; Table S2). On the other hand, the CRISPR-mediated defense could have limited the more extensive distribution of these and other putative viruses (e.g., NODE_77, NODE_395, and NODE_396; Table 2) within the C. clathratiforme population. Collectively, however, these findings demonstrate the ongoing interactions between individual phages emerging from the large pool of C. clathratiforme viruses and its host, which eventually determine their distribution in a given environment.

Members of Chlorobium perform anoxygenic photosynthesis using reduced sulfur compounds (e.g., thiosulfate, sulfide, etc.) as electron donors to fixate carbon dioxide. The oxidation of sulfur can proceed via canonical Sox and/or Dsr pathways [71,72]. Genes involved in Sox (soxYZ) and Dsr $(d s r C)$ pathways were previously identified in viral metagenomes [62], though they were absent in GSB-associated viral contigs described in Llorens-Marès et al. [8] and Berg et al. [23]. In addition to these already known AMGs, we identified thiosulfate sulfurtransferase (rhodanese; TST) (Table 2), which catalyzes the transfer of a sulfur atom from thiosulfate to thiophilic acceptors [72]. The thiosulfate sulfurtransferase, by breaking the S-S bond present in thiosulfate, may provide an alternative way of thiosulfate reduction to sulfur and sulfite [73], which subsequently can be used for the biosynthesis of Fe/S clusters, amino acids, various cofactors, redox reactions, and regulatory pathways [72]. Another identified AMG is the thioredoxin-dependent PAPS reductase (cysH; Table 2) involved in assimilatory pathways of sulfate reduction. These 
enzymes take part in the biosynthesis of sulfite by catalyzing the reduction of protein disulfide bonds in PAPS [74]. In addition to these, one ORF was found to encode the iron-sulfur cluster assembly protein (encoded by iscA gene; Table S8) known to take part in the recruitment of intracellular iron during the biogenesis of iron-sulfur clusters, which requires the coordinated incorporation of both iron and sulfur $[75,76]$. The $\mathrm{Fe} / \mathrm{S}$ cluster assembly protein participates in electron transport, redox reactions, and regulatory processes. Thus, although the precise metabolic role of the AMGs mentioned above during infection remains unknown, it might be that $C$. clathratiforme-infecting phages utilize these enzymes to modulate sulfur-oxidation rates toward the increased energy production required for effective phage replication.

Some metagenomic datasets indicated that small single-stranded DNA (ssDNA) phages belonging to Gokushovirinae and a group of unclassified Microviridae are widely distributed in aquatic viral communities $[70,77,78]$, suggesting that these microviruses can infect a broad range of host taxa. The recovery of the Microviridae genome (NODE_396; Table S2) and the detection of CRISPR spacers against this and other microviruses (Table 2) suggest that members of Microviridae can infect $C$. clathratiforme, and that there exists a proactive intracellular defense system to prevent these infections. Further studies, however, are needed to gain a more comprehensive understanding of interactions between Microviridae phages and C. clathratiforme.

\section{Conclusions}

A comprehensive understanding of viral activity in aquatic ecosystems remains limited by the lack of host-contextualized quantitative surveys of viral diversity. This study, using a single-cell sequencing approach, provides viral genomic data experimentally linked to specific ecologically relevant green sulfur bacteria, C. clathratiforme. We showed the existence of a large pool of diverse viruses that have not yet been cultivated and that are distinct from those in public databases and aquatic metagenomes, potentially representing new lineages. We also reported a high level of $C$. clathratiforme population lysogenization and the potential of phages to alter sulfur metabolism and cycling. We anticipate that new genomic information retrieved from C. clathratiforme SAGs will improve our knowledge about phage diversity associated with green sulfur bacteria, abundant in both euxinic waters and in rare habitats such as gypsum karst lakes.

Supplementary Materials: The following are available online at https:/ / www.mdpi.com/article/10 .3390/genes12060886/s1, Figure S1: Rarefaction plots of the four samples taken at the different depths in Lake Kirkilai (Lithuania), Figure S2: Shannon index of OTU diversity and Simpson evenness value at each depth Lake Kirkilai (Lithuania), Figure S3: Neighbor-joining tree reconstruction based on the full length 16S rDNA multiple sequence alignment generated from MAFFT v7. The numbers at nodes refer to bootstrap support values (number of resampling: 1000). The scale bar equals 0.4 substitutions per site. Figure S4: Proteomic tree of 2769 prokaryotic dsDNA viruses including 82 viral contigs found in this study. The dendrogram represents the proteome-wide similarities between C. clathratiforme SAGs-associated viral contigs (red start symbol and red branches) and other prokaryotic viruses (black branches). Branch lengths are logarithmically scaled from the root of the entire proteomic tree. Numbers represent genomic similarity scores $\left(\mathrm{S}_{\mathrm{G}}\right)$ retrieved from normalized tBLASTx bit scores computed from the pairwise viral sequence comparisons. Rings represent viral (inner ring) and host (outer ring) taxonomic classifications. The proteomic tree was generated with ViPTree software v1.9, Figure S5: Neighbor-joining tree reconstructions based on the different marker genes identified in C. clathratiforme SAGs-associated viral contigs. Multiple sequence alignments were generated using MAFFT v7. The numbers at nodes refer to bootstrap support values expressed as percentages (number of resampling: 1000), Table S1: Environmental characteristics of the four sampling sites in Lake Kirkilai (Lithuania), Table S2: Taxonomic classification of the most abundant OTUs ( $>1 \%$ or more of the total reads) throughout the water column of the Lake Kirkilai (Lithuania), Table S3: Single-cell genome assembly statistics, Table S4: General characteristics, taxonomic classification and distribution of $C$. clathratiforme SAGs-associated viral contigs, Table S5: BLASTn search results against IMG/VR dataset (Ecosystem category: Aquatic; accessed June 2021; database version 5.1), 
Table S6: Viral abundance estimates normalized as fragments per kilobase per mapped million reads (FPKM) for each individual C. clathratiforme SAG, Table S7: Genome annotations of C. clathratiforme SAGs-associated viral contigs, Table S8: Similarity matrix of Microviridae phage genomes (RefSeq DB; accessed March 2021) generated using VIRIDIC software, Table S9: Predicted protein coding genes in C. clathratiforme-associated phage sequences, Table S10: List of CRISPR spacer sequences and spacer sequence matches in C. clathratiforme SAGs-associated viral contigs and other known phages identified in the consensus C. clathratiforme genome. File S1. Genome annotation file of C. clathratiforme.

Author Contributions: Conceptualization, S.Š. and G.A.; methodology, G.A., V.J., E.Š., P.V., M.Š. and R.P.; software, S.Š. and G.A.; validation, S.Š. and G.A.; formal analysis, G.A., V.J., E.Š., P.V., M.Š. and R.P.; investigation, G.A., V.J., E.Š., P.V., M.Š. and R.P.; data curation, S.Š., G.A. and R.P.; writingoriginal draft preparation, S.Š.; writing—review and editing, S.Š.; visualization, S.Š.; supervision, S.Š.; project administration, E.Š.; funding acquisition, E.Š. All authors have read and agreed to the published version of the manuscript.

Funding: This research has received funding from the Research Council of Lithuania (LMTLT), agreement No [S-MIP-20-38].

Institutional Review Board Statement: Not applicable.

Informed Consent Statement: Not applicable.

Data Availability Statement: The $16 \mathrm{~S}$ rDNA sequences obtained using the 515F-Y/926R prokaryotic primers set and single cell sequences presented in this article have been submitted to NCBI and are available under BioProject accession number PRJNA562654.

Acknowledgments: The authors are grateful to Vaida Šeputienè (Thermo Fisher Scientific Baltics, Vilnius, Lithuania) for help and support with $16 \mathrm{~S}$ amplicon sequencing.

Conflicts of Interest: The authors declare no conflict of interest.

\section{References}

1. Green, J.; Paget, M. Bacterial redox sensors. Nat. Rev. Microbiol. 2004, 2, 954-966. [CrossRef]

2. Keshri, J.; Pradeep Ram, A.S.; Nana, P.A.; Sime-Ngando, T. Taxonomical resolution and distribution of bacterioplankton along the vertical gradient reveals pronounced spatiotemporal patterns in contrasted temperate freshwater lakes. Microb. Ecol. 2018, 76, 372-386. [CrossRef] [PubMed]

3. İnceoğlu, Ö.; Llirós, M.; Crowe, S.A.; Morana, C.; Darchambeau, F.; Borges, A.V.; Descy, J.P.; Servais, P. Vertical Distribution of functional potential and active microbial communities in meromictic Lake Kivu. Microb. Ecol. 2015, 70, 596-611. [CrossRef] [PubMed]

4. $\quad$ Baatar, B.; Chiang, P.W.; Rogozin, D.Y.; Wu, Y.T.; Tseng, C.H.; Yang, C.Y.; Chiu, H.H.; Oyuntsetseg, B.; Degermendzhy, A.G.; Tang, S.L. Bacterial communities of three saline meromictic lakes in Central Asia. PLoS ONE 2016, 11, e0150847. [CrossRef] [PubMed]

5. Diao, M.; Huisman, J.; Muyzer, G. Spatio-temporal dynamics of sulfur bacteria during oxic-anoxic regime shifts in a seasonally stratified lake. FEMS Microbiol. Ecol. 2018, 94, fiy040. [CrossRef]

6. Tonolla, M.; Peduzzi, S.; Hahn, D.; Peduzzi, R. Spatio-temporal distribution of phototrophic sulfur bacteria in the chemocline of meromictic Lake Cadagno (Switzerland). FEMS Microbiol. Ecol. 2003, 43, 89-98. [CrossRef] [PubMed]

7. Gregersen, L.H.; Habicht, K.S.; Peduzzi, S.; Tonolla, M.; Canfield, D.E.; Miller, M.; Cox, R.P.; Frigaard, N.-U. Dominance of a clonal green sulfur bacterial population in a stratified lake. FEMS Microbiol. Ecol. 2009, 70, 30-41. [CrossRef]

8. Llorens-Marès, T.; Liu, Z.; Allen, L.Z.; Rusch, D.B.; Craig, M.T.; Dupont, C.L.; Bryant, D.A.; Casamayor, E.O. Speciation and ecological success in dimly lit waters: Horizontal gene transfer in a green sulfur bacteria bloom unveiled by metagenomic assembly. ISME J. 2017, 11, 201-211. [CrossRef] [PubMed]

9. Danza, F.; Ravasi, D.; Storelli, N.; Roman, S.; Lüdin, S.; Bueche, M.; Tonolla, M. Bacterial diversity in the water column of meromictic Lake Cadagno and evidence for seasonal dynamics. PLoS ONE 2018, 13, e0209743. [CrossRef] [PubMed]

10. Weitz, J.S.; Stock, C.A.; Wilhelm, S.W.; Bourouiba, L.; Coleman, M.L.; Buchan, A.; Follows, M.J.; Fuhrman, J.A.; Jover, L.F.; Lennon, J.T.; et al. A multitrophic model to quantify the effects of marine viruses on microbial food webs and ecosystem processes. ISME J. 2015, 9, 1352-1364. [CrossRef]

11. Zimmerman, A.E.; Howard-Varona, C.; Needham, D.M.; John, S.G.; Worden, A.Z.; Sullivan, M.B.; Waldbauer, J.R.; Coleman, M.L. Metabolic and biogeochemical consequences of viral infection in aquatic ecosystems. Nat. Rev. Microbiol. 2020, 18, 21-34. [CrossRef]

12. Sullivan, M.B. Viromes, not gene markers, for studying double-stranded DNA virus communities. J. Virol. 2015, 89, $2459-2461$. [CrossRef] 
13. Simmonds, P.; Adams, M.J.; Benk, M.; Breitbart, M.; Brister, J.R.; Carstens, E.B.; Davison, A.J.; Delwart, E.; Gorbalenya, A.E.; Harrach, B.; et al. Consensus statement: Virus taxonomy in the age of metagenomics. Nat. Rev. Microbiol. 2017, 15, 161-168. [CrossRef] [PubMed]

14. Wilson, W.H.; Gilg, I.C.; Moniruzzaman, M.; Field, E.K.; Koren, S.; Lecleir, G.R.; Martínez Martínez, J.; Poulton, N.J.; Swan, B.K.; Stepanauskas, R.; et al. Genomic exploration of individual giant ocean viruses. ISME J. 2017, 11, 1736-1745. [CrossRef] [PubMed]

15. Martinez-Hernandez, F.; Fornas, O.; Lluesma Gomez, M.; Bolduc, B.; De La Cruz Peña, M.J.; Martínez, J.M.; Anton, J.; Gasol, J.M.; Rosselli, R.; Rodriguez-Valera, F.; et al. Single-virus genomics reveals hidden cosmopolitan and abundant viruses. Nat. Commun. 2017, 8. [CrossRef] [PubMed]

16. Martínez Martínez, J.; Martinez-Hernandez, F.; Martinez-Garcia, M. Single-virus genomics and beyond. Nat. Rev. Microbiol. 2020. [CrossRef] [PubMed]

17. Mizuno, C.M.; Rodriguez-Valera, F.; Garcia-Heredia, I.; Martin-Cuadrado, A.B.; Ghai, R. Reconstruction of novel cyanobacterial siphovirus genomes from Mediterranean metagenomic fosmids. Appl. Environ. Microbiol. 2013, 79, 688-695. [CrossRef] [PubMed]

18. Mizuno, C.M.; Ghai, R.; Saghaï, A.; López-García, P.; Rodriguez-Valeraa, F. Genomes of abundant and widespread viruses from the deep ocean. MBio 2016, 7, e00805-16. [CrossRef]

19. Danhorn, T.; Young, C.R.; Delong, E.F. Comparison of large-insert, small-insert and pyrosequencing libraries for metagenomic analysis. ISME J. 2012, 6, 2056-2066. [CrossRef]

20. Labonté, J.M.; Swan, B.K.; Poulos, B.; Luo, H.; Koren, S.; Hallam, S.J.; Sullivan, M.B.; Woyke, T.; Eric Wommack, K.; Stepanauskas, R. Single-cell genomics-based analysis of virus-host interactions in marine surface bacterioplankton. ISME J. 2015, 9, 2386-2399. [CrossRef]

21. Munson-McGee, J.H.; Peng, S.; Dewerff, S.; Stepanauskas, R.; Whitaker, R.J.; Weitz, J.S.; Young, M.J. A virus or more in (nearly) every cell: Ubiquitous networks of virus-host interactions in extreme environments. ISME J. 2018, 12, 1706-1714. [CrossRef] [PubMed]

22. Castillo, Y.M.; Sebastián, M.; Forn, I.; Grimsley, N.; Yau, S.; Moraru, C.; Vaqué, D. Visualization of viral infection dynamics in a unicellular eukaryote and quantification of viral production using VirusFISH. bioRxiv 2019, 37-49. [CrossRef]

23. Berg, M.; Goudeau, D.; Olmsted, C.; McMahon, K.D.; Yitbarek, S.; Thweatt, J.L.; Bryant, D.A.; Eloe-Fadrosh, E.A.; Malmstrom, R.R.; Roux, S. Host population diversity as a driver of viral infection cycle in wild populations of green sulfur bacteria with long standing virus-host interactions. ISME J. 2021. [CrossRef] [PubMed]

24. Roux, S.; Hawley, A.K.; Torres Beltran, M.; Scofield, M.; Schwientek, P.; Stepanauskas, R.; Woyke, T.; Hallam, S.J.; Sullivan, M.B. Ecology and evolution of viruses infecting uncultivated SUP05 bacteria as revealed by single-cell- and meta-genomics. eLife 2014, 3, e03125. [CrossRef] [PubMed]

25. Humphries, P.; Baldwin, D.S. Drought and aquatic ecosystems: An introduction. Freshw. Biol. 2003, 48, 1141-1146. [CrossRef]

26. Leibold, M.A.; Holyoak, M.; Mouquet, N.; Amarasekare, P.; Chase, J.M.; Hoopes, M.F.; Holt, R.D.; Shurin, J.B.; Law, R.; Tilman, D.; et al. The metacommunity concept: A framework for multi-scale community ecology. Ecol. Lett. 2004, 7, 601-613. [CrossRef]

27. Taminskas, J.; Marcinkevičius, V. Karst geoindicators of environmental change: The case of Lithuania. Environ. Geol. 2002, 42, 757-766. [CrossRef]

28. Paškauskas, R.; Kučinskienè, A.; Žvikas, A. Sulfate-reducing bacteria in gypsum karst lakes of northern Lithuania. Mikrobiologiya 2005, 74, 823-830. [CrossRef]

29. Krevš, A.; Kučinskienè, A. Vertical distribution of bacteria and intensity of microbiological processes in two stratified gypsum Karst Lakes in Lithuania. Knowl. Manag. Aquat. Ecosyst. 2011, 2. [CrossRef]

30. Krevš, A.; Kučinskienè, A.; Kuisienè, N. Anoxygenic phototrophic bacteria from gypsum karst lakes of Lithuania. Inland Water Biol. 2014, 7, 25-33. [CrossRef]

31. Imhoff, J.F. The Family Chlorobiaceae. In The Prokaryotes: Other Major Lineages of Bacteria and the Archaea; Rosenberg, E., DeLong, E.F., Lory, S., Stackebrandt, E., Thompson, F., Eds.; Springer: Berlin/Heidelberg, Germany, 2014; pp. 501-514, ISBN 978-3-642-38954-2.

32. Riemann, L.; Leitet, C.; Pommier, T.; Simu, K.; Holmfeldt, K.; Larsson, U.; Hagström, A. The native bacterioplankton community in the central Baltic Sea is influenced by freshwater bacterial species. Appl. Environ. Microbiol. 2008, 74, 503-515. [CrossRef] [PubMed]

33. Parada, A.E.; Needham, D.M.; Fuhrman, J.A. Primers for marine microbiome studies. Environ. Microbiol. 2016, 18, 1403-1414. [CrossRef]

34. Shen, W.; Le, S.; Li, Y.; Hu, F. SeqKit: A cross-platform and ultrafast toolkit for FASTA/Q file manipulation. PLoS ONE 2016, 11, e0163962. [CrossRef] [PubMed]

35. Rognes, T.; Flouri, T.; Nichols, B.; Quince, C.; Mahé, F. VSEARCH: A versatile open source tool for metagenomics. PeerJ 2016, 4, e2584. [CrossRef] [PubMed]

36. Mahé, F.; Rognes, T.; Quince, C.; de Vargas, C.; Dunthorn, M. Swarm: Robust and fast clustering method for amplicon-based studies. PeerJ 2014, 2, e593. [CrossRef]

37. Quast, C.; Pruesse, E.; Yilmaz, P.; Gerken, J.; Schweer, T.; Yarza, P.; Peplies, J.; Glöckner, F.O. The SILVA ribosomal RNA gene database project: Improved data processing and web-based tools. Nucleic Acids Res. 2013, 41, D590-D596. [CrossRef]

38. McMurdie, P.J.; Holmes, S. phyloseq: An R package for reproducible interactive analysis and graphics of microbiome census data. PLoS ONE 2013, 8, e61217. [CrossRef] [PubMed] 
39. Bankevich, A.; Nurk, S.; Antipov, D.; Gurevich, A.A.; Dvorkin, M.; Kulikov, A.S.; Lesin, V.M.; Nikolenko, S.I.; Pham, S.O.N.; Prjibelski, A.D.; et al. SPAdes: A new genome assembly algorithm and its applications to single-cell sequencing. J. Comput. Biol. 2012, 19, 455-477. [CrossRef]

40. Parks, D.H.; Imelfort, M.; Skennerton, C.T.; Hugenholtz, P.; Tyson, G.W. CheckM: Assessing the quality of microbial genomes recovered from isolates, single cells, and metagenomes. Genome Res. 2015, 25, 1043-1055. [CrossRef]

41. Kieft, K.; Zhou, Z.; Anantharaman, K. VIBRANT: Automated recovery, annotation and curation of microbial viruses, and evaluation of viral community function from genomic sequences. Microbiome 2020, 8, 90. [CrossRef] [PubMed]

42. Wood, D.E.; Lu, J.; Langmead, B. Improved metagenomic analysis with Kraken 2. Genome Biol. 2019, 20, 257. [CrossRef]

43. Menzel, P.; Ng, K.L.; Krogh, A. Fast and sensitive taxonomic classification for metagenomics with Kaiju. Nat. Commun. 2016, 7, 11257. [CrossRef]

44. Uritskiy, G.V.; DiRuggiero, J.; Taylor, J. MetaWRAP-A flexible pipeline for genome-resolved metagenomic data analysis. Microbiome 2018, 6, 158. [CrossRef] [PubMed]

45. $\mathrm{Wu}$, Y.-W.; Simmons, B.A.; Singer, S.W. MaxBin 2.0: An automated binning algorithm to recover genomes from multiple metagenomic datasets. Bioinformatics 2016, 32, 605-607. [CrossRef] [PubMed]

46. Alneberg, J.; Bjarnason, B.S.; de Bruijn, I.; Schirmer, M.; Quick, J.; Ijaz, U.Z.; Lahti, L.; Loman, N.J.; Andersson, A.F.; Quince, C. Binning metagenomic contigs by coverage and composition. Nat. Methods 2014, 11, 1144-1146. [CrossRef] [PubMed]

47. Kang, D.D.; Froula, J.; Egan, R.; Wang, Z. MetaBAT, an efficient tool for accurately reconstructing single genomes from complex microbial communities. PeerJ 2015, 3, e1165. [CrossRef]

48. Seemann, T. Prokka: Rapid prokaryotic genome annotation. Bioinformatics 2014, 30, 2068-2069. [CrossRef] [PubMed]

49. Russel, J.; Pinilla-Redondo, R.; Mayo-Muñoz, D.; Shah, S.A.; Sørensen, S.J. CRISPRCasTyper: Automated Identification, Annotation, and Classification of CRISPR-Cas Loci. CRISPR J. 2020, 3, 462-469. [CrossRef] [PubMed]

50. Mitrofanov, A.; Alkhnbashi, O.S.; Shmakov, S.A.; Makarova, K.S.; Koonin, E.V.; Backofen, R. CRISPRidentify: Identification of CRISPR arrays using machine learning approach. Nucleic Acids Res. 2021, 49, e20. [CrossRef] [PubMed]

51. Zhang, R.; Mirdita, M.; Levy Karin, E.; Norroy, C.; Galiez, C.; Söding, J. SpacePHARER: Sensitive identification of phages from CRISPR spacers in prokaryotic hosts. Bioinformatics 2021. [CrossRef] [PubMed]

52. Nishimura, Y.; Yoshida, T.; Kuronishi, M.; Uehara, H.; Ogata, H.; Goto, S. ViPTree: The viral proteomic tree server. Bioinformatics 2017, 33, 2379-2380. [CrossRef]

53. Roux, S.; Adriaenssens, E.M.; Dutilh, B.E.; Koonin, E.V.; Kropinski, A.M.; Krupovic, M.; Kuhn, J.H.; Lavigne, R.; Brister, J.R.; Varsani, A.; et al. Minimum information about an uncultivated virus genome (MIUVIG). Nat. Biotechnol. 2019, 37, 29-37. [CrossRef] [PubMed]

54. Breitbart, M.; Rohwer, F. Here a virus, there a virus, everywhere the same virus? Trends Microbiol. 2005, 13, 278-284. [CrossRef] [PubMed]

55. Overmann, J.; Pfennig, N. Pelodictyon phaeoclathratiforme sp. nov.; a new brown-colored member of the Chlorobiaceae forming net-like colonies. Arch. Microbiol. 1989, 152, 401-406. [CrossRef]

56. Katoh, K.; Misawa, K.; Kuma, K.; Miyata, T. MAFFT: A novel method for rapid multiple sequence alignment based on fast Fourier transform. Nucleic Acids Res. 2002, 30, 3059-3066. [CrossRef]

57. Moraru, C.; Varsani, A.; Kropinski, A.M. VIRIDIC-A novel tool to calculate the intergenomic similarities of prokaryote-infecting viruses. Viruses 2020, 12, 1268. [CrossRef] [PubMed]

58. Adriaenssens, E.; Brister, J.R. How to Name and Classify Your Phage: An Informal Guide. Viruses 2017, 9, 70. [CrossRef] [PubMed]

59. Crummett, L.T.; Puxty, R.J.; Weihe, C.; Marston, M.F.; Martiny, J.B.H. The genomic content and context of auxiliary metabolic genes in marine cyanomyoviruses. Virology 2016, 499, 219-229. [CrossRef] [PubMed]

60. Mizuno, C.M.; Guyomar, C.; Roux, S.; Lavigne, R.; Rodriguez-Valera, F.; Sullivan, M.B.; Gillet, R.; Forterre, P.; Krupovic, M. Numerous cultivated and uncultivated viruses encode ribosomal proteins. Nat. Commun. 2019, 10. [CrossRef] [PubMed]

61. Tisza, M.J.; Pastrana, D.V.; Welch, N.L.; Stewart, B.; Peretti, A.; Starrett, G.J.; Pang, Y.-Y.S.; Krishnamurthy, S.R.; Pesavento, P.A.; McDermott, D.H.; et al. Discovery of several thousand highly diverse circular DNA viruses. eLife 2020, 9, e51971. [CrossRef] [PubMed]

62. Roux, S.; Brum, J.R.; Dutilh, B.E.; Sunagawa, S.; Duhaime, M.B.; Loy, A.; Poulos, B.T.; Solonenko, N.; Lara, E.; Poulain, J.; et al. Ecogenomics and potential biogeochemical impacts of globally abundant ocean viruses. Nature 2016, 537, 689-693. [CrossRef]

63. Roux, S.; Hallam, S.J.; Woyke, T.; Sullivan, M.B. Viral dark matter and virus-host interactions resolved from publicly available microbial genomes. eLife 2015, 4, e08490. [CrossRef]

64. Mavrich, T.N.; Hatfull, G.F. Bacteriophage evolution differs by host, lifestyle and genome. Nat. Microbiol. 2017,2 , 17112. [CrossRef]

65. Luque, A.; Silveira, C.B. Quantification of lysogeny caused by phage coinfections in microbial communities from biophysical principles. mSystems 2020, 5, 1-9. [CrossRef] [PubMed]

66. Trinh, J.T.; Székely, T.; Shao, Q.; Balázsi, G.; Zeng, L. Cell fate decisions emerge as phages cooperate or compete inside their host. Nat. Commun. 2017, 8. [CrossRef]

67. Erez, Z.; Steinberger-Levy, I.; Shamir, M.; Doron, S.; Stokar-Avihail, A.; Peleg, Y.; Melamed, S.; Leavitt, A.; Savidor, A.; Albeck, S.; et al. Communication between viruses guides lysis-lysogeny decisions. Nature 2017, 541, 488-493. [CrossRef] [PubMed] 
68. Knowles, B.; Silveira, C.B.; Bailey, B.A.; Barott, K.; Cantu, V.A.; Cobián-Güemes, A.G.; Coutinho, F.H.; Dinsdale, E.A.; Felts, B.; Furby, K.A.; et al. Lytic to temperate switching of viral communities. Nature 2016, 531, 466-470. [CrossRef] [PubMed]

69. Howard-Varona, C.; Hargreaves, K.R.; Abedon, S.T.; Sullivan, M.B. Lysogeny in nature: Mechanisms, impact and ecology of temperate phages. ISME J. 2017, 11, 1511-1520. [CrossRef]

70. Angly, F.E.; Felts, B.; Breitbart, M.; Salamon, P.; Edwards, R.A.; Carlson, C.; Chan, A.M.; Haynes, M.; Kelley, S.; Liu, H.; et al. The marine viromes of four oceanic regions. PLoS Biol. 2006, 4, 2121-2131. [CrossRef]

71. Hu, X.; Liu, J.; Liu, H.; Zhuang, G.; Xun, L. Sulfur metabolism by marine heterotrophic bacteria involved in sulfur cycling in the ocean. Sci. China Earth Sci. 2018, 61, 1369-1378. [CrossRef]

72. Wasmund, K.; Mußmann, M.; Loy, A. The life sulfuric: Microbial ecology of sulfur cycling in marine sediments. Environ. Microbiol. Rep. 2017, 9, 323-344. [CrossRef] [PubMed]

73. Harada, M.; Yoshida, T.; Kuwahara, H.; Shimamura, S.; Takaki, Y.; Kato, C.; Miwa, T.; Miyake, H.; Maruyama, T. Expression of genes for sulfur oxidation in the intracellular chemoautotrophic symbiont of the deep-sea bivalve calyptogena okutanii. Extremophiles 2009, 13, 895-903. [CrossRef] [PubMed]

74. Grein, F.; Ramos, A.R.; Venceslau, S.S.; Pereira, I.A.C. Unifying concepts in anaerobic respiration: Insights from dissimilatory sulfur metabolism. Biochim. Biophys. Acta-Bioenerg. 2013, 1827, 145-160. [CrossRef]

75. Ding, H.; Clark, R.J.; Ding, B. IscA mediates iron delivery for assembly of iron-sulfur clusters in IscU under the limited accessible free iron conditions. J. Biol. Chem. 2004, 279, 37499-37504. [CrossRef] [PubMed]

76. Qian, L.; Zheng, C.; Liu, J. Characterization of iron-sulfur cluster assembly protein isca from Acidithiobacillus ferrooxidans. Biochemistry 2013, 78, 244-251. [CrossRef]

77. López-Bueno, A.; Tamames, J.; Velázquez, D.; Moya, A.; Quesada, A.; Alcamí, A. High diversity of the viral community from an Antarctic lake. Science 2009, 326, 858-861. [CrossRef] [PubMed]

78. Tucker, K.P.; Parsons, R.; Symonds, E.M.; Breitbart, M. Diversity and distribution of single-stranded DNA phages in the North Atlantic Ocean. ISME J. 2011, 5, 822-830. [CrossRef] 